\title{
Isopod Parasite, Nerocila Depressa (Edwards, 1840) Infestation in Thryssa Stenosoma (Wongratana, 1983) as New Host, and First Record from Narmada Estuary, West Coast of India
}

\author{
AMIYA SAHOO \\ Central Inland Fisheries Research Institute https://orcid.org/0000-0002-3183-8565 \\ D. Bhakta
}

Central Inland Fisheries Research Institute

D. K. Meena

Central Inland Fisheries Research Institute

D. Sadhukhan

Central Inland Fisheries Research Institute

T. Das

Central India Institute of Medical Sciences

S. P. Kamble

Central Inland Fisheries Research Institute

D. Majhi

Central Inland Fisheries Research Institute

S. Samanta

Central Inland Fisheries Research Institute

Basanta K. Das ( $\sim$ basantakumard@gmail.com )

Central Inland Fisheries Research Institute

\section{Research Article}

Keywords: Nerocila depressa, Thryssa stenosoma, Narmada estuary, India

Posted Date: June 3rd, 2021

DOI: https://doi.org/10.21203/rs.3.rs-566240/v1

License: (c) (i) This work is licensed under a Creative Commons Attribution 4.0 International License. Read Full License 


\section{Abstract}

The study reported Thryssa stenosoma, as new host for isopod Nerocila depressa, infestation. Furthermore, the report is of first to record Nerocila depressa from the Narmada, the largest estuary of west coast of India. Thryssa stenosoma forms a commercially important fish species at Bhadbhut, a part of the Narmada estuary. The prevalence of isopod infestation was $17.39 \%$ with mean intensity 2.8 in $T$. stenosoma, indicating the low, at the present ecological conditions. Looking at the future proposed developmental river valley projects at Bhadbhut estuarine zone, our present information would form baseline to the parasitic diseases in estuarine fishes in Narmada estuary, India.

\section{Introduction}

Fishes are considered to be a global source of animal protein, contributing about $17 \%$ of the total animal protein intake and $7 \%$ of all proteins (Fish site, 2020). Currently the Global fish production is estimated to have reached about 179 million tonnes (FAO, 2020). Generally, ectoparasitic isopods inflict serious threats to fishes and crustaceans both in the wild and aquaculture system (Thatcher \& Blumenfeldt 2001; Chu et al. 2010). Isopod parasites are common in many commercially important fish species, causing various levels of damages (Sethi 2012). Among the parasitic isopods in fish, crustacean ectoparasite are dominant groups and are around 450 parasitic species known from fresh and marine waters and about $25 \%$ of crustacean parasites belonging to copepod, Brachiura and isopods, are found in the marine environment (Miiller and Anders 1986). Cymothoidae, a family of crustacean isopods is found in the marine, freshwater and brackish water environment and widely distributed all over the world. Hadfield et al. (2017) reported that the family Cymothoidae consists of 43 genera which are associated with many commercially important fishes. Cymothoids are ectoparasites having a long slender body and easy to identify (Smith et al 2014). These isopods are generally found in the shallow waters because they are less resistant to the water flow (Smith et al. 2014). Most of the cymothoid are considered to be as, highly host and site-specific (Rameshkumar et al. 2013). The first record of cymothoids in Indian marine fishes was reported in the year 1783, but still, records of cymothoids infestation in Indian fishes are limited (Trilles et al. 2011). Nerocila is a large genus, including 65 species and once infest to a suitable host, starts their parasitic life for feeding on blood and tissues(Trilles 1979; Trilles 1972; Trilles et al. 2013: Rameshkumar and Samuthirapandian 2013).

The present study was a part of regular fish catch composition study in the estuarine zone of the Narmada river, Gujarat with a major focus at Bhadbhut. Narmada estuary is the largest estuary in the west coast of India with an area about 30,000 ha supporting livelihood to the millions fishers. The Ministry of Water Resources and Ganga Rejuvenation, Government of India, India has proposed a mega multipurpose barrage project at Bhadbhut, which will create a freshwater reservoir to cater the water need. In this background, during our regular fish sample collection, Nerocila depressa was recorded for the first time in Thryssa stenosoma.

\section{Materials And Methods}


Thryssa stenosoma, was collected from a bag net (10 mm cod end mesh size) catch composition during

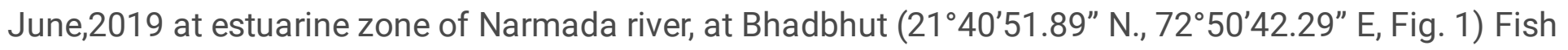
identification was done based on taxonomic key characters (Talwar and Kacker, 1984). A total of 22 fish T. stenosoma were collected and examined for presence of ectoparasites on different parts including skin, gill and buccal cavity. On site, ectoparasites were isolated from the skin of the infested fish specimen and fixed in alcohol formalin acetic acid (AFA) as per Woodland (2006). Total body length and width of the parasite was measured by vernier caliper. The parasite was dissected for drawing of the mouthparts and appendages using camera lucida attached to the microscope. The parasite morphological identification was made based on the well reported descriptions (Bowman and Tareen 1983; Bruce and Nelson 1988; Trilles et al. 2011; Ravichandran et al. 2019) and image was captured by using stereo zoom microscope (Zeiss) and Nikon. Furthermore, the specimen was submitted to the Zoological Survey of India (ZSI), Kolkata for further identification and specimen deposit.

\section{Results}

Isolated ectoparasite was identified as Nerocila depressa (Crustacea, Isopoda, Cymothoidae) by the Department of Crustacean, Zoological Survey of India (ZSI), Kolkata, India, and as per the morphological characteristics description cited by (Bowman and Tareen 1983; Bruce and Nelson 1988; Trilles et al. 2011; Ravichandran et al. 2019). The specimen with Registration Number - C 8036/2 was submitted to the National Repository Centre, ZSI, Kolkata. The size of the isopods was recorded as $23-27 \mathrm{~mm}$ in length and $17-19 \mathrm{~mm}$ in width. The colour of the parasite was observed light brown, two distinct dark strips along the lateral side of the body which is continued up to the exopods of uropods (Fig. 2B, C, D). Parasite was about three times longer than width, widest at pereonites 5 and 6 , terminal margin of cephalon broadly rounded; pereonites $2-4$ subequal, perionite 1 and $5-7$ are longest, posterolateral angle of perionites 1-6 not produced, perionite 7 produced backward; coxae of pereonites 1-7 produced in a rounded process, last three reaching beyond posterior of pereonites; pleonites 1 and 2 longest, and their ventrolateral margins are acutely directed posteriorly; pleonites $3-5$ laterally produced and acute; pleotelson slightly wider than long, with a median point; pereiopods 1-7 gradually longer than each other, without any spines; uropodal exopod 2 times longer than endopod (Fig. 3A-P).

Based on the morphological characteristics, the fish was identified as Thryssa stenosoma belonging to genus Thryssa, family Engraulidae and order Clupeiformes. The fish was found infested with isopod parasite in the caudal peduncle region; just below the lateral line and facing towards the head of the host in parallel (Fig. 2A). A total of 46 fin fish species with length ranged from 41-196 mm were collected from the bag net catch composition and has been observed for parasitic presence. The prevalence of the ectoparasite was $17.39 \%$ with mean intensity of 2.8 (Table 1). Interestingly, fish of average $165 \mathrm{~mm}$ were infested with this ectoparasite. No parasites were reported in the gill or in the buccal cavity.

\section{Discussion}


Nerocila depressa was found attached to the skin of Thryssa stenosoma from the estuarine zone of the Narmada river, India. This is the first report on $N$. depressa infestation in Thryssa stenosoma as a new host and first record from the Narmada estuary, the largest estuary in the west coast of India. Till date, this species is recorded in many fishes species viz. in Opisthopterus turdoore (Bal and Joshi 1959), Sardinella fimbriata (Bruce and Harrison-Nelson 1988)), Sardinella albella (Printrakoon and Purivirojkul 2011), Coilia dussumieri (Aneesh et al. 2013), Sardinella gibbosa (Trilles et al. 2013), Selaroides leptolepis, Carangoides malabaricus (Rameshkumar et al. 2013), Setipinna tenuifilis, Alectic indicus, Netuma bilineata (Kumar et al. 2017), Lepturacanthus pantului, Lagocephalus lunaris (Balakrishnan and Tudu, 2020) as indicated in the Table 2, justifying the marine and estuarine fish species are the major host of infestation and the target tissue. Furthermore, in all these reported fish species external body surface i.e skin was found to be the infestation site indicating the target tissue as skin/muscle, particularly in the caudal peduncle region; just below the lateral line which provide suitable site for attachment and feeding. Printrakoon and Purivirojkul (2011) reported that $N$. depressa was most intensively infested by the parasite, especially in the upper pectoral fin area of Sardinella albella. Further the authors also reported that the hooks of the pereopods penetrates into the skin and supports for attachment, while the mouthpart helps in exposing the underlaying tissue for feeding. Our study also showed similar result of skin, a target site for the attachment. We could not record any isopods in the gill chamber or in the buccal chamber could be due to the larger size of the parasite. Furthermore, we could observe these parasites majorly infest fish of average size of $165 \mathrm{~mm}$ or more from the collected samples. Though we could not get much sample above the $165 \mathrm{~mm}$ to validate statistically, the host size and parasitic infestation, we could observe that larger size group are mostly infested. However, this needs further scientific validation.

In the present study, the prevalence of $N$. depressa was $17.39 \%$ with the mean intensity 2.8 . While, Printrakoon and Purivirojkul (2011) showed 54\% prevalence of $N$. depressa in Sardinela albella. This underlines the prevalence percentage could vary from fish species to species indicating host suitability depending upon the several factors including the body shape, movement, and the scale pattern in fishes also significant role in parasitic infestation (Printrakoon \& Purivirojkul, 2011). Ali \& Aboyadak, (2018) reported that the intensity of isopod's prevalence depends on the swimming speed of the fish. Therefore, it is assumed that the Thryssa stenosoma might have faster swimming behaviour than the Sardinela albella though both are under the same order Clupeiformes.

\section{Conclusions}

This is a record of new fish host for Nerocila depressa in Thryssa stenosoma. Furthermore, the report of isopod Nerocila depressa is also for the first time from Narmada estuary, India. The prevalence of infestation was $17.39 \%$ with a mean intensity 2.8 indicating low prevalence as compared to other fish Sardinela albella as reported. As there is strong proposal for development of river valley project at Bhadbhut, a part of Narmada estuary, this report could serve as base line information for post development changes that might happen to the Narmada estuary. 


\section{Declarations}

Acknowledgements

The authors are also thankful to the Dr. S. Mitra, Scientist and Director, Zoological Society of India, Kolkata for parasite identification and support.

\section{Conflict of Interests}

The authors have no conflict of interest

\section{Authors' contributions}

AKS: Design, writing and final editing, BKD: Supervision and editing DB: Fish sample collection and identification DS\&TD: Parasite sample analysis and submission to ZSI DKM\&SPK: Parasite collection and identification SS: Coordination

\section{References}

1. Aneesh PT, Sudha K, Arshad K, AnilKumar G \& Trilles JP (2013) Seasonal fluctuation of the prevalence of cymothoids representing the genus Nerocila (Crustacea, Isopoda), parasitizing commercially exploited marine fishes from the Malabar Coast, India. Acta parasitologica 58: 80-90.

2. Bal D and Joshi U (1959) Some new isopod parasites on fishes. Journal of the Bombay Natural History Society 56: 563-369.

3. Balakrishnan S and Tudu P (2020) New host records for Nerocila depressa Milne Edwards, 1840 (Crustacea, Isopoda, Cymothoidae) from Digha coast, Bay of Bengal, India.

4. Bleeker P (1857) Recherches sur les crustacés de l'Inde archipélagique/par P. Bleeker.

5. Bowman TE and Tareen IU (1983) Cymothoidae from fishes of Kuwait Arabian Gulf (Crustacea: Isopoda). Smithsonian Contributions to Zoology

6. Bruce N (1987) Australian Pleopodias Richardson, 1910, and Anilocra Leach, 1818 (Isopoda: Cymothoidae), crustacean parasites of marine fishes. Records of the Australian Museum 39: 85-130.

7. Bruce NL and Harrison-Nelson EB (1988) New records of fish parasitic marine Isopod Crustaceans (Cymothoidae, subfamily Anilocrinae) from the Indo-West Pacific. Proceedings of the Biological Society of Washington 101: 585-602.

8. Chu K, Muhamad ZJ, Bruce N (2010) Corallananodosa (Schioedte and Meinert, 1879)(Crustacea: Isopoda: Corallanidae), attacking freshwater fish at the Durian Tunggal Dam, Melaka, Malaysia. Asian Fisheries Science,23(1),116-124

9. FAO (2020) The State of World Fisheries and Aquaculture 2020. https://doi.org/10.4060/ca9231en 10. Fish site (2020) The State of World Fisheries and Aquaculture 2020 (fao.org) 
11. Hadfield K, Horton T, Bruce N, Schotte M (2017) Mothocya Costa in hope, 1851. 2008 onwards). World Marine, Freshwater and Terrestrial Isopod Crustaceans database. Accessed through: http://www.marinespecies.org/aphia.php.

12. Kumar AA, Rameshkumar G. Ravichandran S, Nagarajan R, Prabakaran K, Ramesh M (2017) Distribution of isopod parasites in commercially important marine fishes of the Miri coast, East Malaysia. Journal of parasitic diseases, 41, 55-61.

13. Miiller H and Anders K (1986) Diseases and parasites of marine fishes. Miiller, Kiel, 85-93.

14. Parimala, s. 1984. Nerocila pigmentata Bal \& Joshi (Isopoda: Cymothoidae) parasitic on Nematalosa nasus (Bloch). Journal of the Marine Biological Association of India 21: 180-181.

15. Printrakoon C and Purivirojkul W (2011). Prevalence of Nerocila depressa (Isopoda, Cymothoidae) on Sardinella albella from a Thai estuary. Journal of sea research 65: 322-326.

16. Rameshkumar $\mathrm{G}$ and Ravichandran S (2014) Problems caused by isopod parasites in commercial fishes. Journal of Parasitic Diseases 38: 138-141.

17. Rameshkumar G, Ravichandran S, Ramesh M (2016) Distribution of isopod parasites in Carangid fishes from Parangipettai, Southeast coast of India. Journal of Parasitic Diseases 40: 124-128.

18. Rameshkumar G, Ravichandran S , Sivasubramanian K (2013) Invasion of parasitic isopods in marine fishes. J Coast Life Med 1: 99-105.

19. Rameshkumar G , Samuthirapandian R (2013) Histopathological changes in the skins and gills of some marine fishes due to parasitic isopod infestation. journal of coastal life medicine 1: 12-18.

20. Ravichandran S, Vigneshwaran P ,Rameshkumar G (2019) A taxonomic review of the fish parasitic isopod family Cymothoidae Leach, 1818 (Crustacea: Isopoda: Cymothooidea) of India. Zootaxa 4622: 1-99.

21. Sethi S (2012) Occurrence of isopod parasites in clupeids off Chennai coast, India. Indian Journal of Fisheries 59:117-123.

22. Smit N J, Bruce N L, Hadfield K A (2014). Global diversity of fish parasitic isopod crustaceans of the family Cymothoidae. Intl. J. Parasitol. Parasites. Wildl. 3, 188-197.

23. Talwar, P. K. and Kacker, R. K. (1984). Commercial Sea Fishes of India. Zoological Survey of India, Calcutta, 997.

24. Thatcher VE, Blumenfeldt CL, (2001)Anilocramontti sp. n.(Isopoda, Cymothoidae) a parasite of caged salmon and trout in Chile. RevBras de Zool 18(Suppl.1),269-276

25. Trilles JP (1972). Sur quatre isopodes cymothoides du Pacifique (Nouvelle Caledonie). Cahiers de I'Office de Recherche Scientifiques et Techniques Outre Mers, série Océanographique 10: 3-17.

26. Trilles JP, Rameshkumar G , Ravichandran S (2013) Nerocila species (Crustacea, Isopoda, Cymothoidae) from Indian marine fishes. Parasitology research 112: 1273-1286.

27. Trilles JP, Ravichandran S , Rameshkumar G (2011) A checklist of the Cymothoidae (Crustacea, Isopoda) recorded from Indian fishes. Acta Parasitologica 56: 446-459. 
28. Trilles J (1975) Les cymothoidae (isopoda, flabellifera) des cotes francaises. li. Les anilocridae schioedte et meinert, 1881. Genres anilocra leach, 1818 et nerocila leach, 1818.

29. Trilles J (1979) Les Cymothoidae (Isopoda, Flabellifera; Parasites de Poissons) du Rijksmuseum van Natuurlijke Historie de Leiden: II. Afrique, Amérique et régions Indo-Ouest-Pacifiques. Zoologische Mededelingen 54:245-275.

30. Trilles J (1994) Les Cymothoidae (Crustacea, Isopoda) du monde (Prodrome pour une faune). Stud Mar 21: 1-288.

\section{Tables}

Table 1 Prevalence and mean intensity of Nerocila depressa infestation in Thryssa stenosoma

\begin{tabular}{|llllll|}
\hline Fish sp. & $\begin{array}{l}\text { No. of fish } \\
\text { examined }\end{array}$ & $\begin{array}{l}\text { No of parasite fish } \\
\text { infested }\end{array}$ & Prevalence\% & $\begin{array}{l}\text { No. of } \\
\text { parasite/fish }\end{array}$ & $\begin{array}{l}\text { Mean } \\
\text { intensity }\end{array}$ \\
\hline $\begin{array}{l}\text { Thryssa } \\
\text { stenosoma }\end{array}$ & 46 & 8 & 17.39 & 23 & 2.8 \\
\hline
\end{tabular}

Table 2 Host range of Nerocila depressa infestation and the target site for attachment and feeding 


\begin{tabular}{|c|c|c|c|c|}
\hline Host Species & Family & Site of attachment & Location & Reference \\
\hline $\begin{array}{l}\text { Opisthopterus } \\
\text { turtoor }\end{array}$ & Pristigasteridae & - & - & $\begin{array}{l}\text { (Bal and Joshi } \\
\text { 1959) }\end{array}$ \\
\hline $\begin{array}{l}\text { Sardinella } \\
\text { fimbriata }\end{array}$ & Clupeidae & $\begin{array}{l}\text { Flank, posterior to the } \\
\text { dorsal fin }\end{array}$ & $\begin{array}{l}\text { Starfish } \\
\text { bay,Hongkong }\end{array}$ & (Bruce 1988) \\
\hline $\begin{array}{l}\text { Sardinella } \\
\text { albella }\end{array}$ & Clupeidae & $\begin{array}{l}\text { upper pectoral fin, } \\
\text { between pectoral and } \\
\text { pelvic fin, the } \\
\text { upper pelvic fin, } \\
\text { between pelvic and } \\
\text { anal fin, the upper } \\
\text { anal fin, under dorsal } \\
\text { fin and the caudal } \\
\text { peduncle. }\end{array}$ & Thai estuary & $\begin{array}{l}\text { (Printrakoon and } \\
\text { Purivirojkul 2011) }\end{array}$ \\
\hline $\begin{array}{l}\text { Opisthopterus } \\
\text { tardoore }\end{array}$ & Pristigasteridae & Body surface & $\begin{array}{l}\text { Malabar coast, } \\
\text { India }\end{array}$ & $\begin{array}{l}\text { (Aneesh et al. } \\
\text { 2013) }\end{array}$ \\
\hline $\begin{array}{l}\text { Coilia } \\
\text { dussumieri }\end{array}$ & Engraulidae & Body surface & $\begin{array}{l}\text { Malabar coast, } \\
\text { India }\end{array}$ & $\begin{array}{l}\text { (Aneesh et al. } \\
\text { 2013) }\end{array}$ \\
\hline $\begin{array}{l}\text { Sardinella } \\
\text { gibbosa }\end{array}$ & Clupeidae & Body surface & $\begin{array}{l}\text { Pazhaiyar, } \\
\text { Tamil Nadu } \\
\text { coasts in South } \\
\text { India }\end{array}$ & (Trilles et al. 2013) \\
\hline \multirow[t]{2}{*}{$\begin{array}{l}\text { Selaroides } \\
\text { leptolepis }\end{array}$} & Carangidae & Body surface & $\begin{array}{l}\text { Parangipettai, } \\
\text { Southeast } \\
\text { coast of India } \\
\text { Miri coast, East } \\
\text { Malaysia }\end{array}$ & $\begin{array}{l}\text { (Rameshkumar } \\
\text { and } \\
\text { Samuthirapandian } \\
\text { 2013); }\end{array}$ \\
\hline & & & & $\begin{array}{l}\text { (Rameshkumar et } \\
\text { al., 2016) }\end{array}$ \\
\hline $\begin{array}{l}\text { Carangoides } \\
\text { malabaricus }\end{array}$ & Carangidae & Body surface & $\begin{array}{l}\text { Miri coast, East } \\
\text { Malaysia }\end{array}$ & $\begin{array}{l}\text { (Rameshkumar et } \\
\text { al. 2016) }\end{array}$ \\
\hline $\begin{array}{l}\text { Setipinna } \\
\text { tenuifilis }\end{array}$ & Engraulidae & Body surface & $\begin{array}{l}\text { Miri coast, East } \\
\text { Malaysia }\end{array}$ & $\begin{array}{l}\text { (Kumar et al., } \\
\text { 2017) }\end{array}$ \\
\hline Alectis indicus & Carangidae & Body surface & $\begin{array}{l}\text { Miri coast, East } \\
\text { Malaysia }\end{array}$ & $\begin{array}{l}\text { (Kumar et al. } \\
2017 \text { ) }\end{array}$ \\
\hline
\end{tabular}




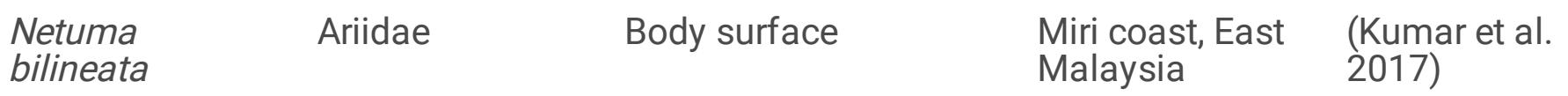

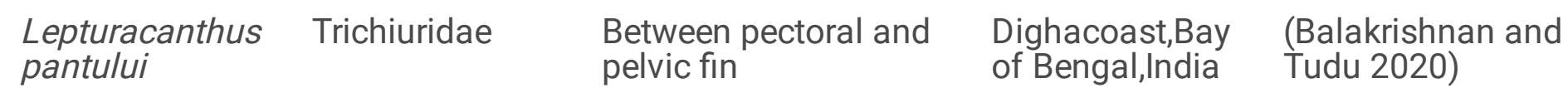

\begin{tabular}{|c|c|c|c|c|}
\hline $\begin{array}{l}\text { Lagocephalus } \\
\text { lunaris }\end{array}$ & Tetraodontidae & Upper pectoral fin & $\begin{array}{l}\text { Dighacoast, } \\
\text { Bay of } \\
\text { Bengal,India }\end{array}$ & $\begin{array}{l}\text { (Balakrishnan and } \\
\text { Tudu 2020) }\end{array}$ \\
\hline
\end{tabular}

\section{Figures}

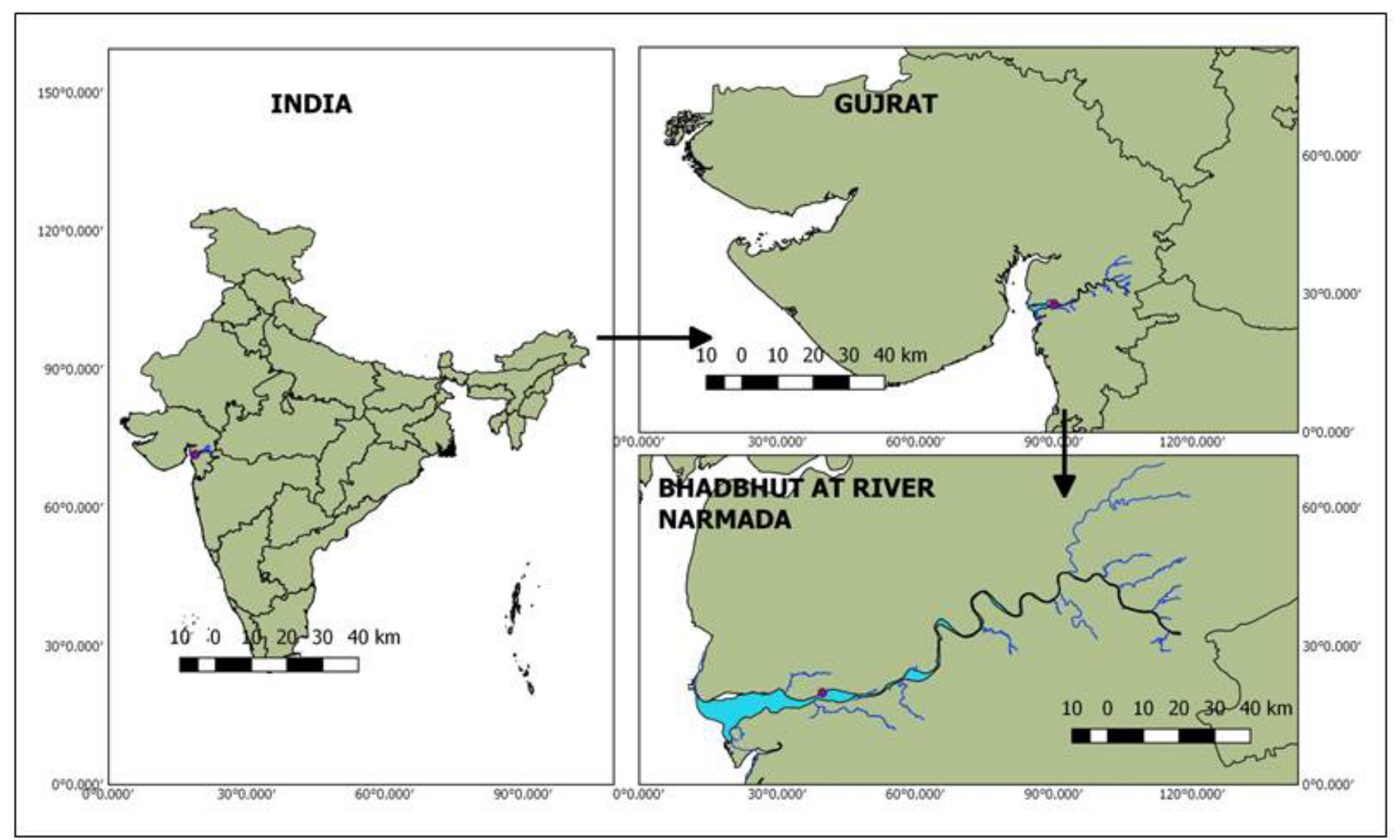

\section{Figure 1}

GIS map showing the sampling area Note: The designations employed and the presentation of the material on this map do not imply the expression of any opinion whatsoever on the part of Research Square concerning the legal status of any country, territory, city or area or of its authorities, or concerning the delimitation of its frontiers or boundaries. This map has been provided by the authors. 


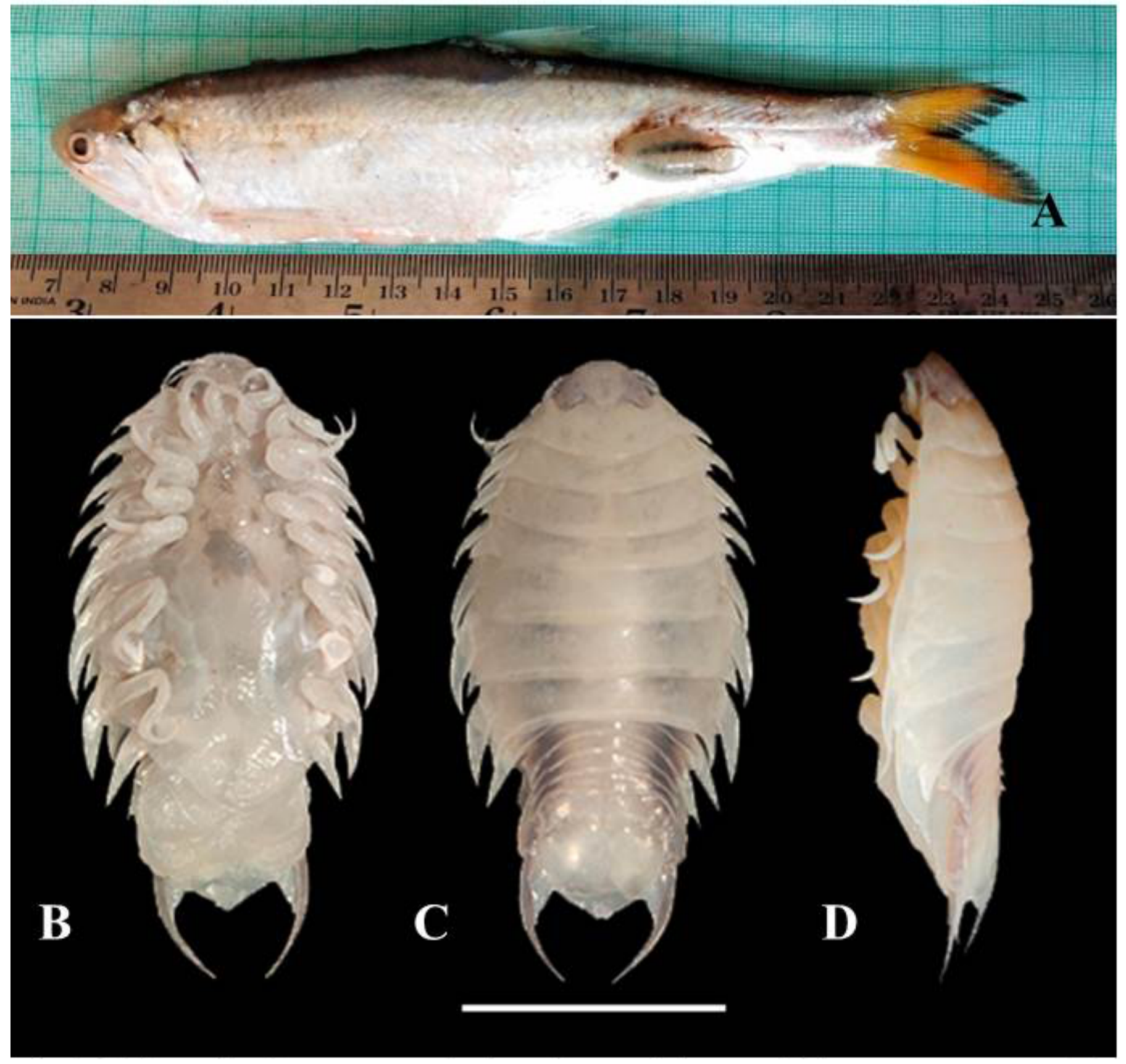

Figure 2

A Nerocila depressa attached to the caudal part of Thryssa stenosoma B ventral, C dorsal \& D lateral view of N.depressa 

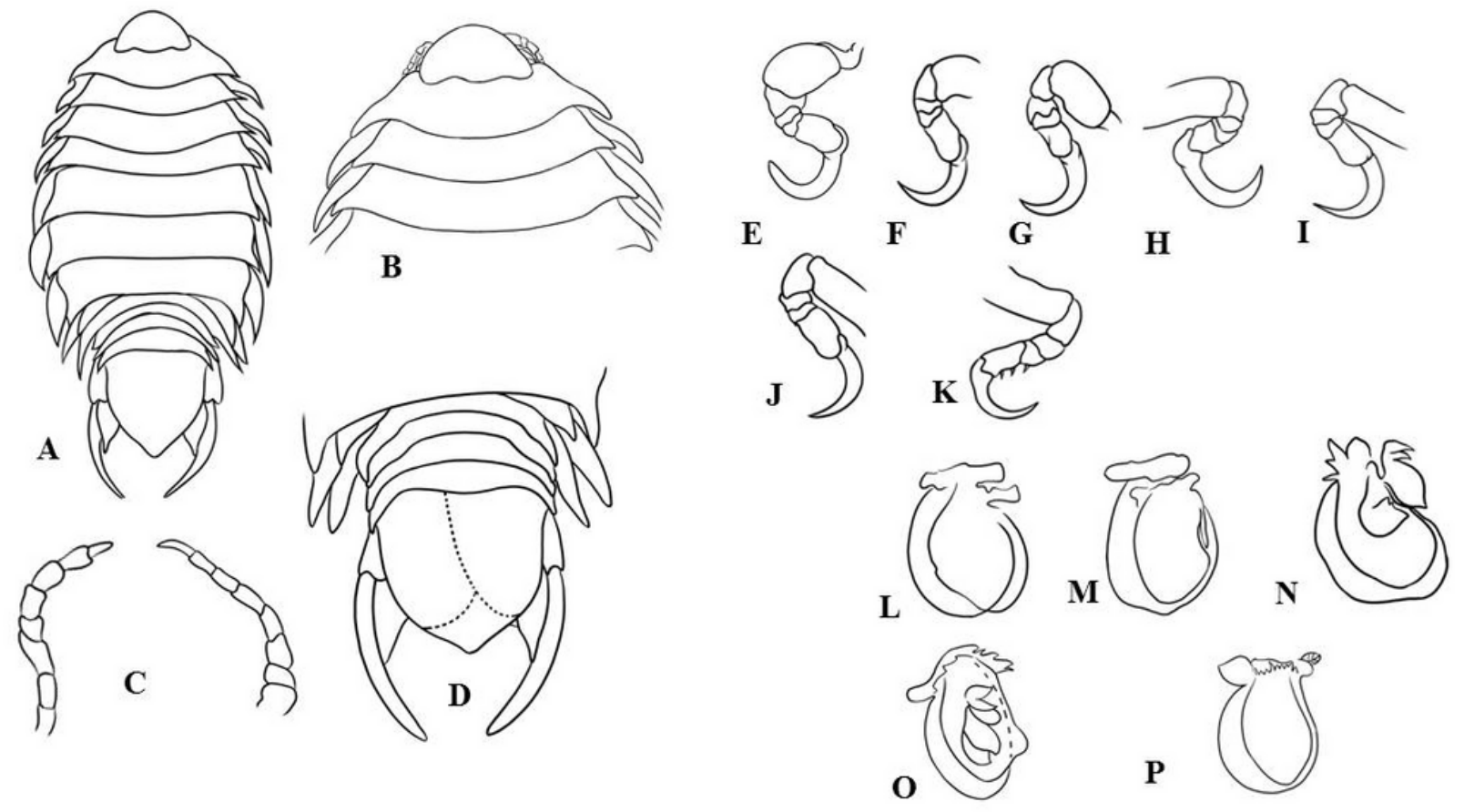

Figure 3

N.depressa (female) A Dorsal view B Pleon (dorsal view) C antenna D E-K pereopods(right side) 1-7 L-P pleopods 1-5(right side) 